\title{
The Influence of Brand Image and Product Innovation on Purchasing Decision of Kopi Kenangan at Tunjungan Plaza Surabaya
}

\author{
Gladys Adella Permatasari \\ Faculty of Economics and Business Narotama University Surabaya \\ gladys.apermatasari@gmail.com
}

\begin{abstract}
The development and growth of the culinary business is currently increasing in Indonesia, especially in Surabaya, especially coffee shops, this is marked by the rise of restaurants, cafes and coffee shops. Kopi Kenangan is one of the shops that popularized a typical Indonesian coffee milk drink which is popular with the name "Es Kopi Kenangan Mantan". This study aims to analyze whether brand image and product innovation partially influence purchasing decisions of Kopi Kenangan at Tunjungan Plaza Surabaya and whether the brand image and product innovation also simultaneously influences the purchasing decision of Kopi Kenangan at Tunjungan Plaza Surabaya. This research is a quantitative study. Total sample of this study is 104 Consumers of Kopi Kenangan in Tunjungan Plaza. The type of sample used is simple random sample. The researcher uses interviews, questionnaires and observations to obtain data. The results show that partially brand image and product innovation have a significant effect on purchasing decisions. Brand Image and Product Innovation have a simultaneous effect on purchasing decisions for Kopi Kenangan at Tujungan Plaza.
\end{abstract}

\section{Keywords :}

Brand Image, Kopi Kenangan, Product Innovation, Purchasing Decisions

\section{Introduction}

Amid the proliferation of local coffee shops and the aggressiveness of networked coffee shops, Kopi Kenangan is stealing the attention of coffee lovers in the country. Kopi Kenangan has successfully conquered two big investors, Alpha JWC and Sequoia Capital, so that they are willing to invest US \$ 8 million and US \$ 20 million respectively. Not even two years into Indonesia, the local coffee shop Kopi Kenangan has won the trust of two global investors. In the first phase, October 2018, Kopi Kenangan succeeded in obtaining funding from Alpha JWC of US \$ 8 million. And most recently, at the end of June 2019, Kopi Kenangan again pocketed fresh funds from Sequoia Capital of US \$ 20 million. As a local brand, Kopi Kenangan has a vision to go to a global market. In this case, using the USP (Unique Selling Proposition) coffee and palm sugar raw materials from Indonesia. "Milk coffee is a very unique trend from Indonesia. For that, through Kopi Kenangan, we hope to introduce Indonesian products through milk coffee with palm sugar.

Kopi Kenangan is one of the shops that popularized a typical Indonesian coffee milk drink which is popular with the name "Es Kopi Kenangan Mantan". One of the competitors of Kopi Kenangan is Kopi Janji Jiwa, Kopi Kulo, Fore Coffe and fellow local coffee brands.

Table 1. Development of The Opening of Coffee Shop Outlets in Indonesia

\begin{tabular}{cccc}
\hline Number & Cafe Name & First Opening & Total Outlets \\
\hline 1 & Kopi Kenangan & 2017 & 175 \\
2 & Fore Coffe & 2018 & 100 \\
3 & Kulo & 2018 & 300 \\
4 & Janji Jiwa & 2018 & 500 \\
\hline
\end{tabular}

Source: Researcher survey results, 2020

Even now, Kopi Kenangan has released their own application which can be downloaded by the public. With their application called Kopi Kenangan, people can order and buy Kopi Kenangan through the application. The great thing is, we don't need to queue when ordering via the application, just come to the nearest Kopi 
Kenangan shop and take our order. Kopi Kenangan, which is currently pioneering from the ground up in terms of online ordering applications, is working hard to be competitive.

Kopi Kenangan has become one of the contemporary coffees that millennials don't want to miss for consumption. Not only the taste of coffee that is not inferior to foreign brands, the name of the Kopi Kenangan menu attracts the attention of young people, even makes it difficult to move on. Kopi Kenangan Mantan is their mainstay menu. Even now, Kopi Kenangan has released their own application which can be downloaded by the public. With their application called Kopi Kenangan, people can order and buy Kopi Kenangan through the application. The great thing is, we don't need to queue when ordering via the application, just come to the nearest Kenangan Coffee shop and take our order.

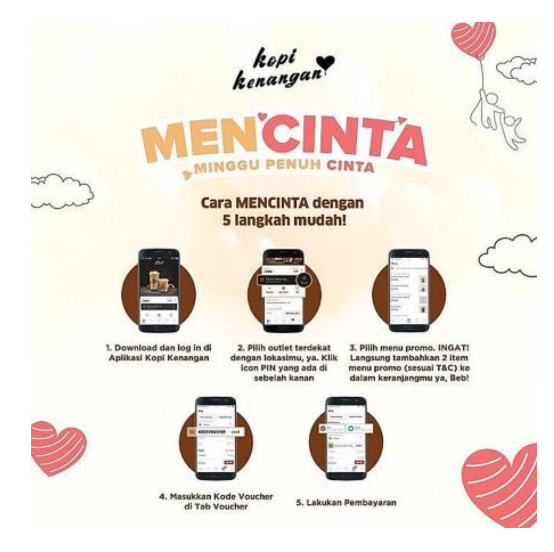

Figure 1. Kopi Kenangan Online Ordering Application Data

Source: Kopi Kenangan, 2020

Based on the above background, researcher is interested in conducting research with the title "The Influence of Brand Image and Product Innovation on Purchasing Decision of Kopi Kenangan at Tunjungan Plaza Surabaya".

Based on the background description of the problem above, the problem formulations in this study are:

1) Do brand image and product innovation partially influence purchasing decisions at the Kopi Kenangan Shop at Tunjungan Plaza Surabaya?

2) Do Brand Image and product innovation simultaneously influence purchasing decisions at the Kopi Kenangan Shop at Tunjungan Plaza Surabaya?

\section{Literature Review}

Supranto. Limakrisna (2011) state that brand image is what consumers think and feel when they hear or see a brand and what consumers learn about the brand. Thus, it can be concluded that a brand image is a set of brand associations that consumers can feel and think about that are created and maintained by marketers to form in the minds of consumers.

Then according to Kotler dan Keller (2009) brand image is a number of beliefs, ideas, and impressions that a person holds about an object. Meanwhile, brand image is the perception and belief held by consumers, as reflected in the associations embedded in consumers' memories.

According to Fandy Tjiptono (2008), what is meant by brand image is a description of the association and consumer confidence in a particular brand. There are several indicators used to measure Brand Image according to Lutiary Eka Ratri (2007) that is:

1) Product attributes, are things related to the brand itself, such as packaging, taste, price, and so on.

2) consumer benefits, is the use of products from that brand.

3) Brand personality, is an association regarding the personality of a brand if the brand is a human.

Meanwhile, according to Trott $\mathrm{p}$ (2008) innovation is management regarding all activities including the process of idea formation, technology development, manufacturing and marketing processes for the existence of new and developed products. Thus, it can be said that innovation is a change made by a company, both in terms of development and creation of something new, where these changes can be accepted by the market and have a positive impact on the company's development. Product innovation is a consumer perception that views a product or service as a new variant. Product innovation in this study refers to the opinion Kristian, nela (2012) that is: 
1) Line expansion is the use of strategies to expand the market share of the product's sales.

2) New products, products that are traded, have fresh or new conditions so that they attract consumers.

According to Setiadi (2010) sebuying behavior implies that individual activities are directly involved in exchanging money for goods and services and in the decision-making process that determines these activities. A consumer's decision to buy a product always involves physical activity (in the form of direct consumer activity through the stages of the purchase decision-making process) and mental activity (when consumers judge the product according to certain criteria set by individuals).

Purchasing decisions taken by buyers are actually a collection of a number of organized decisions. According Adingsih (2005) every purchase decision has a structure of seven components. These components include :
a. Decisions about product types
b. Decisions about product form
c. Decisions about brands
d. Decisions about sales
e. Keputuasan about the number of products
f. Decision about when to buy
g. Decisions about how to pay

\section{Conceptual Framework}

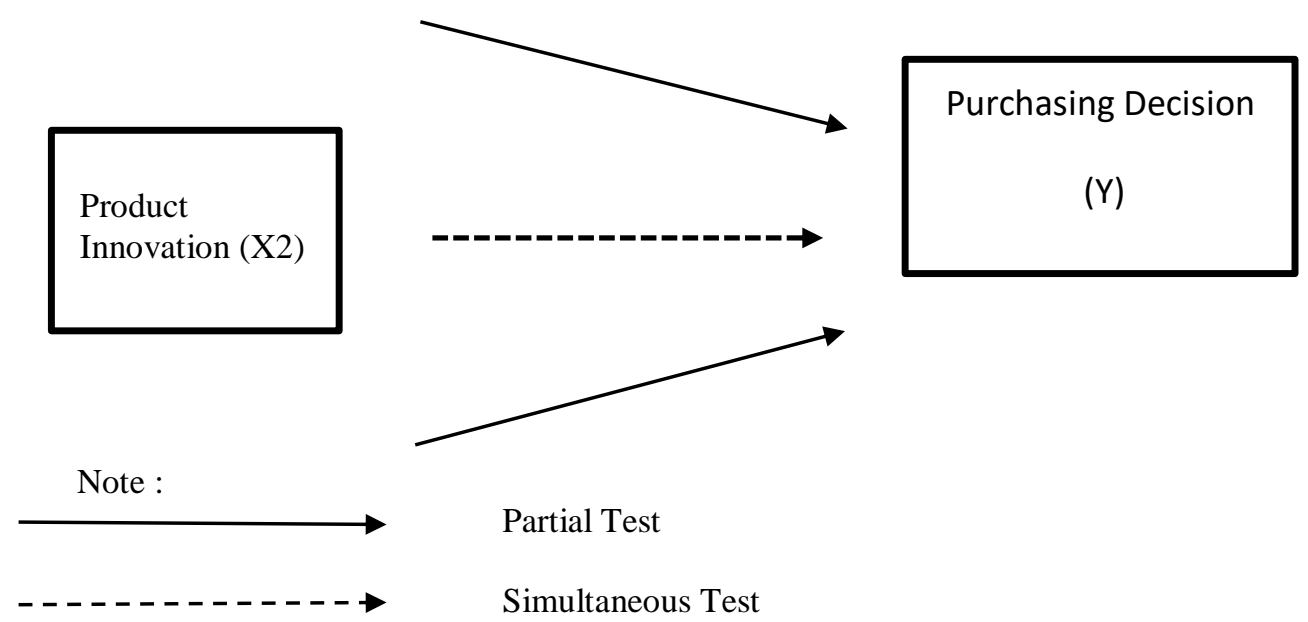

\section{Research Method}

This type of research is quantitative. Researcher took a sample of 104 consumers of Kopi Kenangan at Tunjungan Plaza. The sample type used is simple random sampling. Data collection techniques in this study using interviews, questionnaires, and observations. The data in this study were processed using the Statistical Package for Social Science (SPSS) 18.0 for Windows program. Data analysis in this study is to use multiple linear regression analysis.

Researcher used a partial test ( $\mathrm{T}$ test) and simultaneous test (F test) to test the hypothesis in this study.

The hypothesis formulation for the partial test ( $\mathrm{t}$ statistical test) in this study is as follows:

1) $\mathrm{Ho}=$ independent variable $(\mathrm{X})$ partially has no significant effect on the dependent variable $(\mathrm{Y})$.

2) $\mathrm{Ha}=$ independent variable $(\mathrm{X})$ partially has a significant effect on dependent variable $(\mathrm{Y})$.

The hypothesis formulation for the simultaneous test (f statistical test) in this study is as follows:

1) $\mathrm{Ho}=$ independent variable $(\mathrm{x})$ simultaneously has no significant effect on the dependent variable (y).

2) $\mathrm{Ha}=$ independent variable $(\mathrm{x})$ simultaneously has a significant effect on the dependent variable $(\mathrm{y})$.

The basis for making a decision with a significant level of 0.05 is as follows:

1) If the sig value $>0.05$, the decision Ho is accepted and Ha is rejected, it means that the independent variable (x) simultaneously has no significant effect on variable $(y)$.

2) If the sig value $<0.05$, the decision Ho is rejected and $\mathrm{Ha}$ is accepted, it means that the independent variable (x) simultaneously has a significant effect on the dependent variable (y). 


\section{Results and Discussion}

The data in this study were obtained from the results of distributing questionnaires to 104 consumers of Kopi Kenangan Tunjungan Plaza. Based on the results of the respondents' answers in the distributed questionnaires, the respondent's data can be described based on gender, age, latest education, occupation, income rankings, and purchase estimates of respondents as follows:

Table 2. Characteristics Based on the Gender of Respondents

\begin{tabular}{|c|c|c|c|c|c|}
\hline & & & Gender & & \\
\hline & & Frequency & Percent & Valid Percent & Cumulative Percent \\
\hline Valid & Men & 34 & 32,7 & 32,7 & 32,7 \\
\hline & Women & 70 & 67,3 & 67,3 & 100,0 \\
\hline & Total & 104 & 100,0 & 100,0 & \\
\hline
\end{tabular}

From the table above it can be seen that most of the respondents that is 34 respondents or $32.7 \%$ are men, and 70 respondents or $67.3 \%$ are women.

Table 3. Characteristics Based on Age of Respondents

\begin{tabular}{cccccc}
\hline & & \multicolumn{4}{c}{ Age Group } \\
& Frequency & Percent & Valid Percent & Cumulative Percent \\
\hline Valid & $17-20$ & 3 & 2,9 & 2,9 & 2,9 \\
& Years Old & & & & 57,7 \\
$21-25$ & 57 & 54,8 & 54,8 & \\
& Years Old & & & & \\
$26-30$ & 37 & 35,6 & 35,6 & 93,3 \\
& Years Old & & & & \\
& $31-40$ & 7 & 6,7 & 6,7 & 100,0 \\
& Years Old & & & & \\
Total & 104 & 100,0 & 100,0 & \\
\hline
\end{tabular}

From the table above it can be seen that most of the respondents, that is 3 respondents or $2.9 \%$ aged 17 20 years, 57 respondents or $54.8 \%$ aged $21-25$ years, 37 respondents or $35.6 \%$ aged $26-30$ years, 7 respondents or $6.7 \%$ aged $31-40$ years.

Table 4. Characteristics Based on Respondents' Last Education

\begin{tabular}{cccccc}
\hline \multicolumn{5}{c}{ Last Education } & \\
& & Frequency & Percent & Valid Percent & Percent \\
\hline Valid & High school & 42 & 40,4 & 40,4 & 40,4 \\
& Bachelor & 57 & 54,8 & 54,8 & 95,2 \\
& Postgraduate & 5 & 4,8 & 4,8 & 100,0 \\
& Total & 104 & 100,0 & 100,0 & \\
\hline
\end{tabular}

From the table above it can be seen that most of the respondents, that is 42 respondents or $40.4 \%$ were high school students, 57 respondents or $54.8 \%$ were bachelor, 5 respondents or $4.8 \%$ were postgraduate. 
Table 5. Characteristics Based on Occupation of Respondents

\begin{tabular}{|c|c|c|c|c|c|}
\hline \multicolumn{6}{|c|}{ Occupation } \\
\hline & & Frequency & Percent & Valid Percent & $\begin{array}{l}\text { Percent } \\
\text { Pumulative }\end{array}$ \\
\hline \multirow{5}{*}{ Valid } & Students & 25 & 24,0 & 24,0 & 24,0 \\
\hline & Government employees & 10 & 9,6 & 9,6 & 33,7 \\
\hline & Private employees & 55 & 52,9 & 52,9 & 86,5 \\
\hline & Housewife & 14 & 13,5 & 13,5 & 100,0 \\
\hline & Total & 104 & 100,0 & 100,0 & \\
\hline
\end{tabular}

From the table above it can be seen that most of the respondents, that is 25 respondents or $24.0 \%$ are students, 10 respondents or $9.6 \%$ are Government employees, 55 respondents or $52.9 \%$ are private employees, 14 respondents or $13,5 \%$ Housewives

Table 6. Characteristics Based on Respondents' Income Level

\begin{tabular}{cccccc}
\hline & & \multicolumn{3}{c}{ Income Level } & \\
& & Frequency & Percent & Valid Percent & Cumulative Percent \\
\hline Valid & $1-2$ Million & 17 & 16,3 & 16,3 & 16,3 \\
& $2-4$ Million & 54 & 51,9 & 51,9 & 68,3 \\
& $4-6$ Million & 33 & 31,7 & 31,7 & 100,0 \\
& Total & 104 & 100,0 & 100,0 & \\
\hline
\end{tabular}

From the table above, it can be seen that most of the respondents, that is 17 respondents or $16.3 \%$, are 1 million -2 million, 54 respondents or $51.9 \%$ are 2 million -4 million, 33 respondents or $31.7 \%$ are 4 million 6 million.

\subsection{T Test (Partial)}

$\mathrm{T}$ test is to test how the influence of each independent variable on the dependent variable.

Table 7. T Test (Partial)

\begin{tabular}{|c|c|c|c|c|c|c|c|c|c|c|c|}
\hline \multicolumn{12}{|c|}{ Coefficients $^{\mathrm{a}}$} \\
\hline \multirow{5}{*}{1} & Model & & & $\begin{array}{c}\text { Standard } \\
\text { zed }\end{array}$ & & & & & & & \\
\hline & & $\begin{array}{r}\text { Unstan } \\
\text { Coeff }\end{array}$ & Irdized & $\begin{array}{c}\text { Coefficie } \\
\text { nts }\end{array}$ & & & & rrelatior & & Collin & $\begin{array}{l}\text { earity } \\
\text { stics }\end{array}$ \\
\hline & (Constant) & $\begin{array}{c}\mathrm{B} \\
-, 250\end{array}$ & $\begin{array}{c}\text { Std. } \\
\text { Error } \\
, 324\end{array}$ & Beta & $\begin{array}{c}\mathrm{t} \\
-, 771\end{array}$ & $\begin{array}{l}\text { Sig. } \\
, 443\end{array}$ & $\begin{array}{l}\text { Zero- } \\
\text { order }\end{array}$ & Partial & Part & $\begin{array}{c}\text { Toleran } \\
\text { ce }\end{array}$ & VIF \\
\hline & $\begin{array}{l}\text { Brand } \\
\text { Image }\end{array}$ & ,692 & ,088 & ,615 & 7,883 & ,000 &, 821 & ,617 & ,421 & , 469 & 2,130 \\
\hline & $\begin{array}{l}\text { Product } \\
\text { Innovation }\end{array}$ & ,362 &, 100 & ,283 & 3,635 & ,000 &, 731 & ,340 & ,194 & ,469 & 2,130 \\
\hline
\end{tabular}

a. Dependent Variable: Keputusan Pembelian

1. Based on the SPSs output above, the significance value of brand image is $0.000<0.05$, it means that brand image has a significant effect on purchasing decisions.

2. The significance value of product innovation as large as $0.000<0.05$ means that product innovation has a significant effect. The 5\% (0.025) significance level of testing includes two-way testing Formula: $\mathrm{df}=\mathrm{n}-\mathrm{k}$ where $\mathrm{n}=$ many observations $\mathrm{K}=$ many variables (free and dependent) $\mathrm{Df}=104-2=102$

3. From these results with a significance level of $5 \%$, the ttable value is 1.98350

4. From the output of the SPSs above, it is known that the tcount of brand image is 7.883> 1.98350, meaning that there is a significant influence between brand image and purchasing decisions.

5. From the output of the SSPS above, it is known that the value of product innovation $t$ count is $3,635>t$ table 1,98350 , meaning that there is a significant influence between product innovation on purchasing decisions. 


\subsection{F TEST (Simultaneous)}

The $\mathrm{F}$ test is used to determine whether the independent variables simultaneously have a significant effect on the dependent variable. The degree of confidence used is 0.05 . If the calculated $F$ value is greater than the $\mathrm{F}$ value according to the table, then the alternative hypothesis, which states that all independent variables simultaneously have a significant effect on the dependent variable.

Tabel 8. F TEST (Simultaneous) ANOVAb

\begin{tabular}{ccccccc}
\hline & Model & Sum of Squares & df & Mean Square & F & Sig. \\
\hline \multirow{2}{*}{1} & Regression & 45,537 & 2 & 22,769 & 124,721 &, $000 \mathrm{a}$ \\
& Residual & 18,438 & 101 &, 183 & & \\
& Total & 63,975 & 103 & & & \\
\hline
\end{tabular}

a. Predictors : (Constant), Product Innovation

b. Depedent Variable : Purchasing Decision

c. Based on the SPSs output above a significance value of $0.000<0.05$ means that simultaneously the perception of brand image and product innovation on purchasing decisions

d. Comparing the magnitude of the number F count with the formula $F$ table: $\mathrm{df} 1=\mathrm{k}-1$ df2 $=\mathrm{n}-\mathrm{k}$

Where $\mathrm{k}=$ number of variables (free and dependent) $\mathrm{n}=$ number of observations / samples df $1=2-1=1$ df $2=104-2=102$

From these results, with a significance level of $5 \%$, the $\mathrm{F}$ table value is 3.93

From the output of the above spss, it is known that the value of F count is $124.721>$ from F table 3.93, it means that brand image and product innovation simultaneously affect purchasing decisions.

Thus it can be said that the second hypothesis which states that "brand image and product innovation simultaneously influence purchasing decisions" is proven empirically true.

\section{Conclusion}

1. The brand image variable (X1) has a partial effect on purchasing decisions, the value of tcount is $7.883>\mathrm{t}$ table 1.98350 with a significance of $0.000<0.05$, which means that brand image affects the purchasing decision at Kopi Kenangan Tunjungan Plaza.

2. Product Innovation Variable (X2) has a partial effect on Purchasing Decisions, the tcount value is 3,635> t table 1.98350 with a significance of $0.000<0.05$, which means that Product Innovation affects Purchasing Decisions at Kopi Kenangan Tunjungan Plaza.

3. The purchasing decision variable (Y) has a simultaneous effect on Brand Image (X1) and Production Innovation $(\mathrm{X} 2)$, which shows fcount $=124.721>$ from $\mathrm{f}$ table 3.09 with a significance of $0.000<0.05$, which means that it has a significant effect on Coffee Purchasing Decisions at Kopi Kenangan Tunjungan Plaza.

\section{References}

Adingsih, S. I. \& S. (2005). "Hubungan Economic Value Added (EVA) Dan Market Value Added (MVA) Pada Perusahaan Publik Yang Terdaftar Di Bursa Efek Jakarta. Jurnal. FE UPN 'Veteran' Yogyakarta, 6(1), 116.

Fandy Tjiptono. (2008). Strategi Pemasaran, Edisi III. CV andi offset.

Kotler dan Keller. (2009). Manajemen Pemasaran. Jilid I. Edisi ke 13. Erlangga.

Kristian, nela, dan nanang wahyudin. (2012). Pengaruh Atribut Produk terhadap Minat Beli Konsumen Mobil Merek Isuzu Elf Studi pada PT. Karya Zirang Utama Isuzu Semarang. Jurnal Ilmu Manajemen Dan Akuntansi, 3(1).

Lutiary Eka Ratri. (2007). Hubungan Antara Citra Merek (Brand Image) operator Seluler Dengan Loyalitas Merek (Brand Loyalty) Pada Mahasiswa Pengguna Telepon Seluler Di Fakultas Ekonomi Reguler Universitas Diponegoro Semarang. Fakultas Psikologi, Undip.

Setiadi, N. J. (2010). Perilaku Konsumen. Cetakan 4. Edisi Revisi. kencana.

Supranto. Limakrisna, N. (2011). Perilaku Konsumen dan Strategi Pemasaran. Mitra Wacana Media.

Trott p. (2008). Innovation Management and New Product Development. Prentice Hall. 